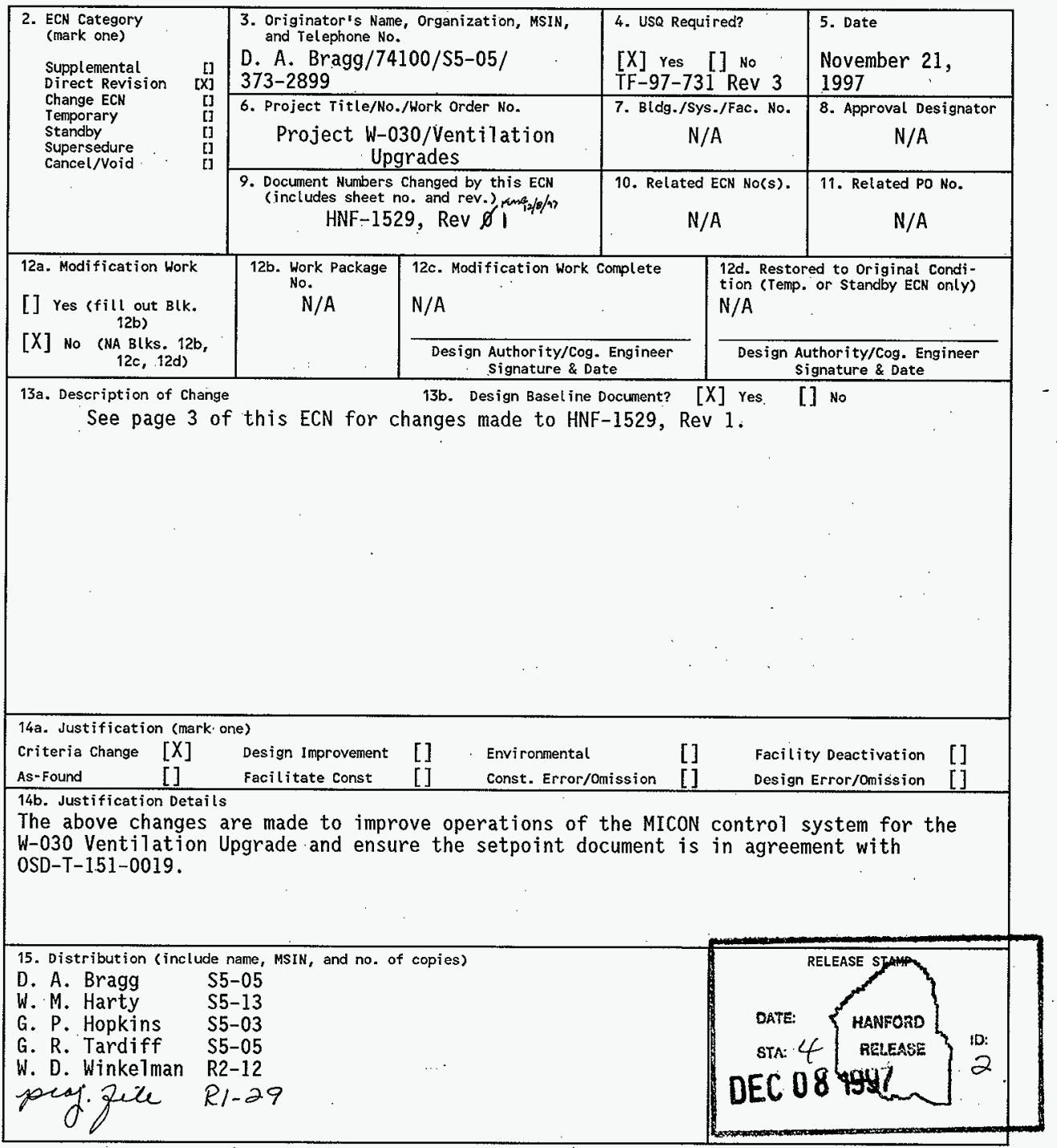


The following changes were made to HNF-1529 Rev 1, and are present in HNF-1529 Rev 2.

1) Page 8: FI-AZKl-3 PV STACK. FLOW:

Change $A 1$ arm High flow rate from 1,000 scfm to 1,050 scfm.

2) Pg 18: PDI-AZK14-1A, PDI-AZK14-1B, PDI-AZK14-2A, PDI-AZK14-2B: Change Alarm Hihi of 5.0 INCH (H2O) to Interlock of 5.0 INCH (H2O)

3) Pg 19: PDI-AZK19-1. Change Alarm Hihi from 9.5 INCH $(\mathrm{H} 20)$ to $15.0 \mathrm{INCH}$ (H20). Added new Hi a 7 arm of 10.0 INCH (H2O).

4) Pg 21: PDI-AZK110-1A \& PDI-AZK110-1B. Change hi a7arm from 2.0 to 2.5 INCH (H20). Change hihi from 2.25 to $3.0 \mathrm{INCH}(\mathrm{H} 20)$.

5) Pg 24:RAH-AZK19-1. Change Alarm High from $500 \mathrm{mrem} / \mathrm{hr}$ to $300 \mathrm{mrem} / \mathrm{hr}$.

6) Pg 25: RAH-AZKI-1. Change Alarm hi from $10 \mathrm{dpm} / \mathrm{ft}^{3}$ to $300 \mathrm{dpm} / \mathrm{ft}^{3}$ for slow a1 arm concentration, and from $600 \mathrm{dpm} / \mathrm{ft}^{3}$ to $7,000 \mathrm{dpm} / \mathrm{ft}^{3}$ for fast a $7 \mathrm{arm}$ concentration. Add 3,000 CPM (Beta Net Count Rate).

7) Pg 26: TAL-AZK18-1B. Added information to show temperature is taken from the airstream outlet, not the condenser cooling coil, and added Lolo alarm of 35 degrees $F$.

8) Page 28: TDIC-AZ-KI2-1B. Change low alarm from 5 degrees $F$ to 17 degrees $F$, and changed controller setpoint from 17 to 25 degrees $F$.

9) Page 30: TI-AZK12-3A \& TI-AZK12-3B. Added ATarm Max to both alarms and added alarm low to TI-AZK12-1B. 


\section{Historical Basis For Analog Input Setpoints, 241-AY \& 241-AZ Tank Farm MICON Automation System}

D. A. Bragg

Lockheed Martin Hanford Company, Rich]and, WA 99352

U.S. Department of Energy Contract DE-AC06-96RL13200

636386

EDT/ECN: ECN 2030

Org Code: 74100 /2/497 Charge Code: E57230

B\&R Code: EW3130010. Total Pages: 33

Key Words: Analog Input, Alarm Set Point, MICON, Project $W-030$, 241-AZ-702 Ventilation Facility

Abstract: This document describes the original basis for selection of the analog input setpoints for the MICON Automation System. In most cases the setpoints were based on vendor supplied information and design requirements. However, some setpoints were also established based on engineering judgement. These setpoints are subject to change as more experience with operation of the ventilation system is obtained.

Revision 1 incorporates minor changes to ensure the document setpoints accurately reflect limits established in OSD-T-151-00019, Rev B-0.

TRADEMARK DISCLAIMER. Reference herein to any specific commercial product, process, or service by trade name, trademark, manufacturer, or otherwise, does not necessarily constitute or imply its endorsement, recommendation, or favoring by the United States Government or any agency thereof or its contractors or subcontractors.

Printed in the United States of America. To obtain copies of this document contact: Document Control Services, P.O. Box 950, Mailstop H6-08, Richland WA 99352, Phone (509) 372-2420; Fax (509) 376-4989.
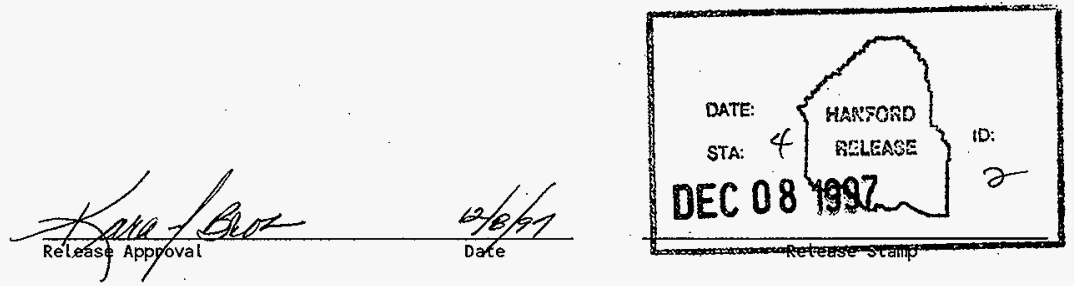


\section{RECORD OF REVISION}

(2) Title

"Historical Basis For Analog Input Setpoints, 241-AY \& 241-AZ Tank Farm MICON Automation System"

CHANGE CONTROL RECORD

\begin{tabular}{|c|c|c|c|c|}
\hline \multirow{2}{*}{ (3) } & \multirow{2}{*}{ Revision } & \multirow{2}{*}{ (4) Description of Change - Replace, Add, and Delete Pages } & \multicolumn{2}{|c|}{ Authorized for Release } \\
\hline & & & (5) Cog. Engr. & (6) Cog. Mgr. \\
\hline & 1 & (7) Changed pages $8,27,30$ per ECN 644182 & D. A. Bragg & D. G. Baide \\
\hline & 2 RS & $\begin{array}{l}\text { Changed pages } 8,18,19,21,25,26,28 \text {, } \\
\text { and } 30 \text { per ECN } 636386\end{array}$ & Dibnazs & -OXBaide $12-1.97$ \\
\hline & & & & \\
\hline & & & & \\
\hline & & & & \\
\hline & & & & \\
\hline & & & & \\
\hline & & & & \\
\hline & & & & \\
\hline & & . & & \\
\hline & & & & \\
\hline & & & & \\
\hline & & & & \\
\hline & & & & \\
\hline & & & & \\
\hline & & & & \\
\hline & & & & \\
\hline & & & & \\
\hline & & & & \\
\hline & & & & \\
\hline & & & & \\
\hline & & & & \\
\hline & & & & \\
\hline & & & & \\
\hline & & & & \\
\hline & & & & \\
\hline & & & & \\
\hline & & . & & \\
\hline & & & & \\
\hline & & & & \\
\hline & & & & \\
\hline & & & & \\
\hline & & & & \\
\hline
\end{tabular}


HNF-1529, Rev 2

Historical Basis For Analog Input Setpoints, 241-AY \& 241-AZ Tank Farm MICON Automation System 


\section{PURPOSE}

The purpose of this document is to establish the basis by which the process variable alarm setpoints to the 241-AY \& 241-AZ Ventilation System were initially selected.

\section{INTRODUCTION}

Project $W-030$ replaces the existing Aging Waste Facility (AWF) ventilation system which removes the heated exhaust air and vapor from the tank vapor spaces. The replacement of the ventilation system is required to update the facility to the most recent operating standards, and to support a new design load of 7 million. BTU/hr from the AWF waste tanks. The new ventilation system is governed by a control and monitoring system called the MICON Automation System (MICON).

The MICON contains alarm setpoints, which if exceeded, annunciate and generate interlocks to provide ventilation system control, and alarm warning.

Process variables are measured by the MICON system as Analog Inputs (AI). In most cases the alarm setpoints are connected directly to the AI variables. In some cases, the setpoints are realized in logic functions. This is done in cases where a time delay is required to prevent spurious alarms during transients. A few alarms are based on digital signals collected through digital input modules. These are generated from local setpoints located in the instruments.

In most instances the MICON process variable alarm setpoints were based upon vendor supplied information and design requirements. However, some setpoints were also determined based solely upon engineering judgement.

The authors of this document anticipate changes will and should occur in some of the setpoints as experience operating the new ventilation system is obtained. This document will periodically be revised to reflect these refinements to the alarm setpoints.

\section{SCOPE}

This document defines the basis by which each of approximately 93 MICON process variable setpoints were created. 


\section{Alarm and Controller Set Points}

241-AZ-702 Ventilation Facility

(Project W-030)

\begin{tabular}{|c|c|}
\hline * Misc \#1 & $\begin{array}{l}\text { AUTOMATIC TRANSFER SWITCHES - TRANSFER TIME, STANDBY TO } \\
\text { NORMAL POWER } \\
\text { Controller Set Point: } 5 \text { minutes } \\
\text { Controller Set Point Basis: Each Automatic Transfer } \\
\text { Switch has an adjustable, internal time delay associated } \\
\text { with the transfer time back to the normal power source. } \\
\text { Originally, the delay was set at } 30 \text { minutes. However, } \\
\text { during testing the lengthy delay lead operations to } \\
\text { believe the Automatic Transfer Switch was not functioning } \\
\text { properly. According to KEH design, there was not a } \\
\text { technical reason for the } 30 \text { minute setting; rather they } \\
\text { recommend not less than a setting of } 5 \text { minutes. }\end{array}$ \\
\hline $\mathrm{FI}-702 \mathrm{~K} 3-1$ & $\begin{array}{l}\text { BLDG STK MONITOR SAMPLE FLOW }(H-2-826394 \text {, Sh } 3 ; H-2-826456 \text { Sh 3; } \\
\text { TMACS-702-13) } \\
\text { A1 arm LOW : } 0.30 \text { SCFM } \\
\text { TMACS ATarm Low: } 0.50 \text { SCFM } \\
\text { Alarm Set Point Basis: See instrument FI-AZ-K1-1. } \\
\text { TMACS A1arm Set Point Basis: See instrument FI-AZ-K1-1. }\end{array}$ \\
\hline$F I-702 K 3-2$ & $\begin{array}{l}\text { BLDG STK RECORD SAMPLE FLOW (H-2-826394, Sh 3; H-2-826456, Sh 3: } \\
\text { TMACS-702-13) } \\
\text { Alarm Low : } 0.30 \text { SCFM } \\
\text { TMACS Al.arm Low: } 0.50 \text { SCFM } \\
\text { Alarm Set Point Basis: See instrument FI-AZ-K1-1. } \\
\text { TMACS Alarm Set Point Basis: See instrument FI-AZ-K1-1. }\end{array}$ \\
\hline
\end{tabular}




\begin{tabular}{|c|c|}
\hline $\mathrm{FI}-702 \mathrm{~K} 3-3$ & 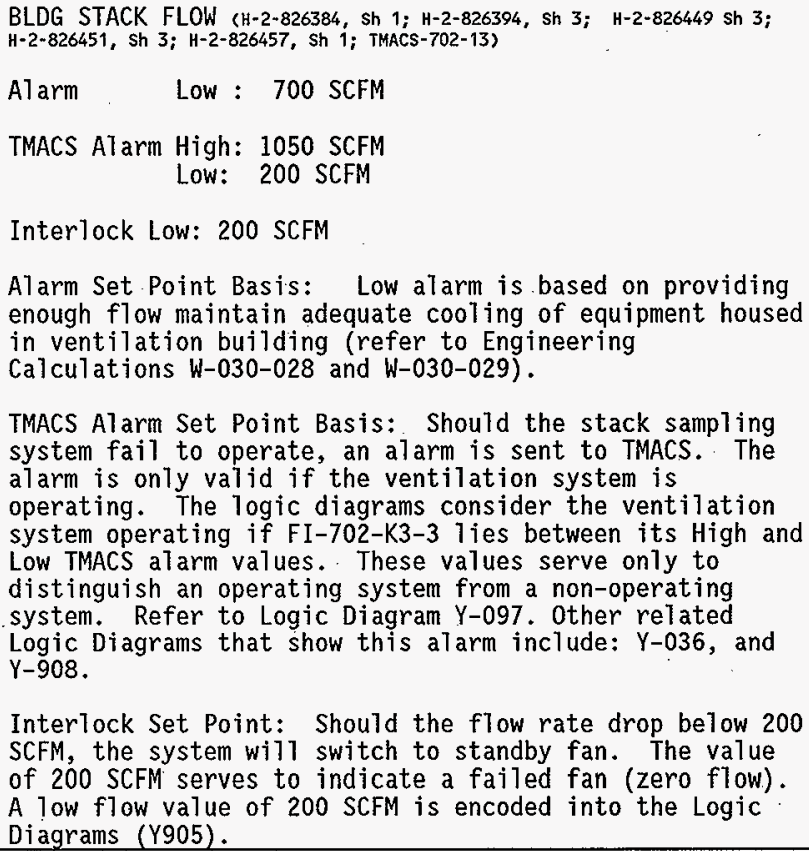 \\
\hline FI-AYIEWR-1 & $\begin{array}{l}\text { 4" EWR-AY1305-M4 FLOW (H-2-826426, Sh 2; H-2-826427, Sh 2) } \\
\text { Alarm LOW : } 170 \text { GPM } \\
\text { Interlock LOW : } 100 \mathrm{GPM} \mathrm{(Pump} \mathrm{Switch)} \\
\text { Alarm Set Point Basis: Procurement Specification W-030- } \\
\text { P14 and the KEH Process System Description document both } \\
\text { identify coolant flow rate as } 192 \text { gpm. Flow rate will be } \\
\text { manually set using valves HV-AY101EWS-1A2. To maintain } \\
\text { adequate tank cooling per design, flow rate should be set } \\
\text { at } 192 \text { gpm or higher. Alarm being set at } 90 \% \text { of design } \\
\text { flow rate. } \\
\text { Interlock Set Point Basis: Should the flow rate fall } \\
\text { below } 100 \text { GPM, the operating recirculation pump will be } \\
\text { shut down, and the standby pump started. Doing allows a } \\
\text { failing pump to be automatically taken out of service. } \\
\text { The set point is arbitrary; it is a threshold value for } \\
\text { no flow rate or a significantly degraded flow rate. The } \\
\text { flow value of } 100 \text { GPM is encoded into the Logic Diagrams } \\
\text { (Y400, Y402, Y404, Y406, Y408, Y410, Y412 and Y4l4). }\end{array}$ \\
\hline
\end{tabular}




\begin{tabular}{|c|c|}
\hline FI-AY1K1-1 & $\begin{array}{l}\text { TK-AY101 AIR INLET FLOW (H-2-826412, Sh 1) } \\
\text { Alarm High: } 550 \text { SCFM } \\
\text { Low: } 50 \text { SCFM } \\
\text { Alarm Set Point Basis: Tank in-flow is dependent upon } \\
\text { tank inleakage (tanks are to be sealed as best is } \\
\text { achievable). Once operating experience is established } \\
\text { (and the degree of sealing determined), the low and high } \\
\text { alarms can be adjusted. Initially, the alarms are being } \\
\text { set at the extremes of the gauges. Note, 50 SCFM is } \\
\text { encoded into the Logic Diagram (e.g. Y196). } \\
\text { Instrumentation range (transmitter) is } 80-600 \text { SCFM. } \\
\text { Flow rates less than approximately } 80 \text { SCFM are reported } \\
\text { as } 0 \text { SCFM. Since the alarm setting is below the minimum } \\
\text { detectable flow rate of } 80 \text { SCFM, and flow rate below the } \\
\text { trasnmitter's range will result in an alarm. }\end{array}$ \\
\hline FI-AYIK $1-2$ & $\begin{array}{l}\text { TK-AY-101 PV AIR FLOW (H-2-826376, Sh 1; H-2-826405, Sh } 1 ; \\
\text { H-2-826420 Sh 5) } \\
\text { Alarm High: } 650 \text { SCFM } \\
\text { Low: } 50 \text { SCFM } \\
\text { Alarm Set Point Basis: Design flow is } 100 \text { SCFM per tank } \\
\text { (Recirculation and Bypass Configuration) and } 500 \text { SCFM for } \\
\text { two tanks (High Heat Configuration). Tank inlet heaters } \\
\text { and filters are sized for } 500 \text { SCFM. Therefore nominal } \\
\text { operating flows are between } 100 \text { SCFM and } 500 \text { SCFM. } \\
\text { However, tank inlet flow (through inlet filter) is } \\
\text { nominaliy } 100-500 \text { SCFM. With a worst case inleakage of } \\
100 \text { CFM, the outlet flow may be as high as } 600 \text { SCFM ( } 500 \\
\text { SCFM + 100 SCFM). The instrumentation range (transmitter } \\
\text { range) is 0-700 SCFM. } \\
\text { Related Logic Diagrams that show this alarm include: } \\
\text { Y-13 and Y-152. }\end{array}$ \\
\hline FI-AY2EWR-1 & $\begin{array}{l}\text { 4" EWR-AY2305-M4 FLOW (H-2-826428, Sh 2; H-2-826429, Sh 2; } \\
\text { H-2-826443, Sh 2) } \\
\text { Alarm LOW : } 170 \text { GPM } \\
\text { Interlock Low : } 100 \text { GPM (Pump Switch) } \\
\text { Related Logic Diagrams that show this alarm include: } \\
\text { Y-404 and Y-406. } \\
\text { Alarm Set Point Basis: See instrument FI-AYI-EWR-1. } \\
\text { Interlock Set Point Basis: See instrument FI-AYI-EWR-1. }\end{array}$ \\
\hline
\end{tabular}




\begin{tabular}{|c|c|}
\hline FI-AY2K1-1 & $\begin{array}{l}\text { TK-AY102 AIR INLET FLOW }(H-2-826412 \text {, Sh } 1) \\
\text { Alarm High: } 550 \text { SCFM } \\
\text { LoW : } 50 \text { SCFM } \\
\text { Alarm Set Point Basis: See instrument FI-AYI-K1-1. }\end{array}$ \\
\hline FI-AY $2 K 1-2$ & $\begin{array}{l}\text { TK-AY-102 PV AIR FLOW (H-2-826376, Sh 1; H-2-826405, Sh 1; } \\
\text { H-2-826420 Sh 7) } \\
\text { Alarm High: } 650 \text { SCFM } \\
\text { Low : } 50 \text { SCFM } \\
\text { Related Logic Diagrams that show this alarm include: } \\
\text { Y-013 and Y-152. } \\
\text { Alarm Set Point Basis: See instrument FI-AYI-Kl-2. }\end{array}$ \\
\hline FI-AZCWR-1 & 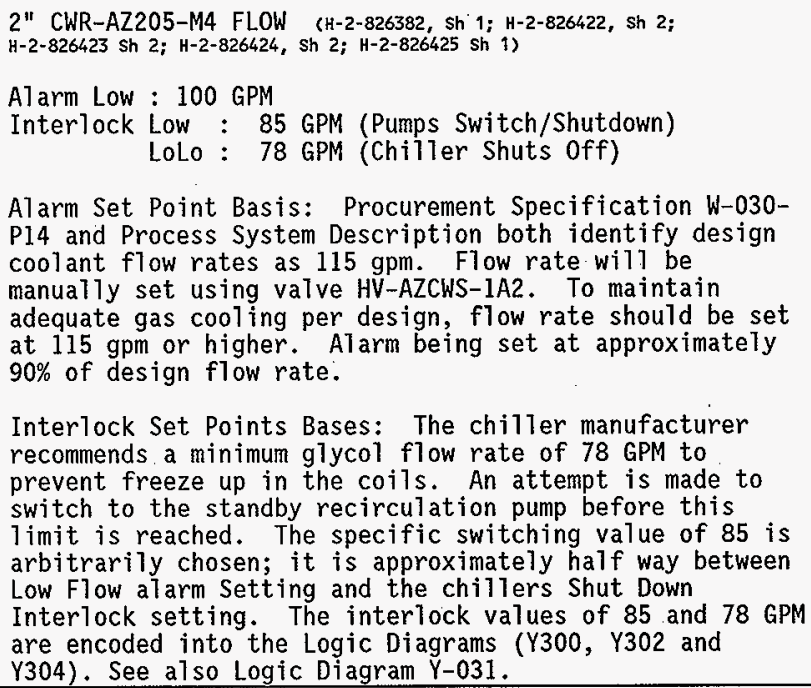 \\
\hline
\end{tabular}




\begin{tabular}{|c|c|}
\hline FI-AZKI-1 & $\begin{array}{l}\text { PV STACK MONITOR SAMPLE FLOW }(\mathrm{H}-2-826394 \text {, Sh 3; H-2-826406, Sh 1; } \\
\text { TMACS-702-11) } \\
\text { Alarm Low : } 0.30 \text { SCFM } \\
\text { TMACS Alarm Low: } 0.50 \text { SCFM } \\
\text { Alarm Set Point Basis: Low alarm should indicate no } \\
\text { flow. Ideally the alarm should occur whenever the sample } \\
\text { flow deviates from the equivalent stack flow (1.e., non- } \\
\text { isokinetic sampling). However such a situation requires } \\
\text { a varying set point. Therefore, the set point is chosen } \\
\text { to indicate a failure of the sample pump, plugging of the } \\
\text { sample lines, or other conditions where no flow would } \\
\text { occur. The low flow alarm is being set to alarm at an } \\
\text { isokinetic flow rate less than the minimum allowable } \\
\text { stack flow rate (200 SCFM) as defined by instrument FI- } \\
\text { AZ-K1-3 (i.e., less than } 0.36 \text { SCFM). Note, that the AMS- } \\
4 \text { CAM unit's low flow alarm also should be loaded with } \\
\text { the above set point (the AMS } 4 \text { contains independent set } \\
\text { points from the MCS; these set points are set in the } \\
\text { field directly into the AMS-4 unit). Keeping the MCS set } \\
\text { point and the AMS-4 set point the same guarantees that } \\
\text { alarms both at the MCS and locally in the Stack } \\
\text { Monitoring Room will occur simultaneously. } \\
\text { TMACS Alarm Set Point Basis: Refer to Logic Yog7. }\end{array}$ \\
\hline FI-AZKI-2 & $\begin{array}{l}\text { PV STACK RECORD SAMPLE FLOW (H-2-826394, Sh 3; H-2-826406, Sh 1; } \\
\text { TMACS-702-11) } \\
\text { ATarm Low : } 0.30 \text { SCFM } \\
\text { TMACS Alarm Low: } 0.50 \text { SCFM } \\
\text { See also Logic Diagram Y-153. } \\
\text { Alarm Set Point Basis: See instrument FI-AZ-K1-1. } \\
\text { TMACS Alarm Set Point Basis: See instrument FI-AZ-KI-1. }\end{array}$ \\
\hline
\end{tabular}




\begin{tabular}{|c|c|}
\hline FI-AZK $1-3$ & 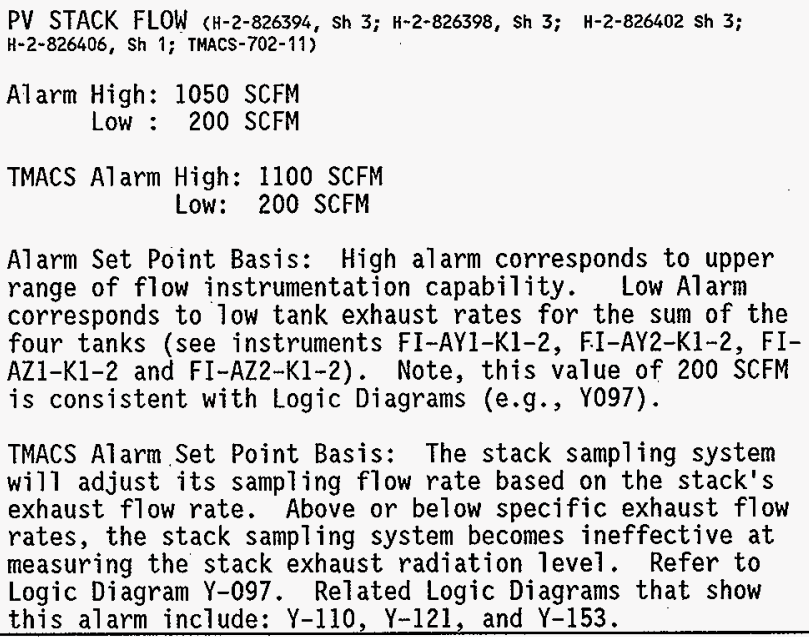 \\
\hline FI-AZ1EWR-1 & $\begin{array}{l}\text { 4". EWR-AZ1305-M4 FLOW (H-2-826430; Sh 2; H-2-826431, Sh 2; } \\
\text { H-2-826444, Sh } 1 \text { ) } \\
\text { A1arm Low : } 295 \text { GPM } \\
\text { Interlock Low : } 100 \mathrm{GPM} \mathrm{(Pump} \mathrm{Switch)} \\
\text { See also Logic Diagram Y-408. } \\
\text { Alarm Set Point Basis: See instrument FI-AY1-EWR-1. } \\
\text { Design flow rate is } 327 \text { gpm. } \\
\text { Interlock Set Point Basis: See instrument FI-AY1-EWR-1. }\end{array}$ \\
\hline$F I-A Z 1 K I-1$ & $\begin{array}{l}\text { TK-AZ101 AIR. INLET FLOW (H-2-826412, sh 1) } \\
\text { Alarm High: } 550 \text { SCFM } \\
\text { Low: } 50 \text { SCFM } \\
\text { Alarm Set Point Basis: See instrument FI-AY1-K1-1. }\end{array}$ \\
\hline$F I-A Z 1 K 1-2$ & $\begin{array}{l}\text { TK-AZ-101 PV AIR FLOW }(H-2-826369 \text {, Sh 1; H-2-826403, Sh 1; } \\
\text { H-2-826421, sh 5) } \\
\text { Alarm High: } 650 \text { SCFM } \\
\text { LOW : } 50 \text { SCFM } \\
\text { See also Logic Diagram Y-150. } \\
\text { Alarm Set Point Basis: See instrument FI-AYI-K1-2. }\end{array}$ \\
\hline
\end{tabular}




\begin{tabular}{|c|c|}
\hline FI-AZ2EWR-I & $\begin{array}{l}\text { 4" EWR-AZ2305-M4 FLOW (H-2-826432, sh 2; H-2-826433, sh 2; } \\
\text { H-2-826444, sh 2) } \\
\text { A7arm Low : } 170 \text { GPM } \\
\text { Interlock LOW : } 100 \text { GPM (Pump Switch) } \\
\text { Related Logic Diagrams that show this alarm include: } \\
\text { Y-412 and Y-414. } \\
\text { Alarm Set Point Basis: See instrument FI-AY1-EWR-1. } \\
\text { Interlock Set Point Basis: See instrument FI-AY1-EWR-I. }\end{array}$ \\
\hline FI-AZ2K1-1 & $\begin{array}{l}\text { TK-AZ102 AIR INLET FLOW (H-2-826412, Sh 1) } \\
\text { Alarm High: } 550 \text { SCFM } \\
\text { Low : } 50 \text { SCFM } \\
\text { Alarm Set Point Basis: See instrument FI-AY1-K1-1. }\end{array}$ \\
\hline FI-AZ2KI-2 & $\begin{array}{l}\text { TK-AZ-102 PV AIR FLOW }(H-2-826369, \text { sh 1; }:-2-826403 \text {, sh 1; } \\
\text { H-2-826421, sh } 7) \\
\text { Alarm High: } 650 \text { SCFM } \\
\text { Low : } 50 \text { SCFM } \\
\text { See also Logic Diagram } Y-150 . \\
\text { Alarm Set Point Basis: See instrument FI-AY1-K1-2. }\end{array}$ \\
\hline II-AZKI5-1A & $\begin{array}{l}\text { AZ-K1-5-1A, PV FAN 1A \% LOAD } \\
\text { Alarm High: } 100 \% \text { LOAD } \\
\text { Set Point Alarm Basis: Vendor information relevant to } \\
\text { Procurement Specification } W-030-P 3 \text { specifies a maximum } \\
\text { current draw of } 20 \text { amps at } 100 \% \text { load. }\end{array}$ \\
\hline II-AZKI5-IB & $\begin{array}{l}\text { AZ-K1-5-1B PV FAN } 1 B \% \text { LOAD } \\
\text { ATarm High: } 100 \% \text { LOAD } \\
\text { Set Point Alarm Basis: See instrument II-AZ-K15-1A. }\end{array}$ \\
\hline $\begin{array}{l}\text { LAH-AZPCSP-1 } \\
\text { LAL-AZPCSP-1 }\end{array}$ & SEAL POT LEVEL \\
\hline
\end{tabular}




\begin{tabular}{|c|c|}
\hline $\begin{array}{l}\text { LALL-AZ-EPRTK } \\
\text { LAL-AZ-EPRTK }\end{array}$ & $\begin{array}{l}\text { DIESEL FUEL TANK LEVEL ALARM (H-2-826393, sh 1) } \\
\text { This is a Discrete Input (DI) alarm. } \\
\text { See also Logic Diagram Y-095. } \\
\text { Low : } 60 \% \\
\text { LoLo: } 10 \% \\
\text { Arbitrary setting }\end{array}$ \\
\hline PDAH-AY $1 K 1-1$ & $\begin{array}{l}\text { AY-101 TANK INLET FILTERS - DIFFERENTIAL PRESSURE } \\
\text { (H-2-826412, sh 1) } \\
\text { This is a Discrete Input (DI) alarm. } \\
\text { Alarm High: } 3 \text { inches(H20) } \\
\text { Alarm Set Point Basis: The High Alarm is consistent with } \\
\text { high alarms for the primary exhaust HEPA filters (see } \\
\text { instrument PDI-AZK14-1A) and building exhaust HEPA } \\
\text { filters (PDI-702K33-1A). The alarm indicates a need to } \\
\text { initiate a JCS work package for filter replacement. Note } \\
\text { that this alarm corresponds to the sum of the pre-filter } \\
\text { differential pressure and the HEPA filter differential } \\
\text { pressure; either or both filters may require replacement } \\
\text { when this alarm activates. Bounding this alarm set point } \\
\text { is the } 1 \text { imit of tank pressure. Since the relative tank } \\
\text { pressure is equal to the sum of pre-filter and HEPA } \\
\text { filter differential pressure plus any other head loss } \\
\text { along the flow's inlet path, the alarm set point should } \\
\text { be less than or equal to the absolute value of the tank's } \\
\text { limiting pressure ( } i \text {.e., the maximum tank vacuum). In } \\
\text { addition, this alarm is well below the manufacturer's } \\
\text { rated limits (refer to PDI-AZK1-1A and PDI-702-K33-1A for } \\
\text { limits and adjust ratings to the inlet filters rated flow } \\
\text { rate). }\end{array}$ \\
\hline PDAH-AY1WF-2 & $\begin{array}{l}\text { AY-101 TOWER BAG FILTER DIFFERENTIAL PRESSURE } \\
\text { This is a Discrete Input (DI) alarm. } \\
\text { Alarm High: } 15 \text { psi } \\
\text { Alarm Set Point Basis: Vendor information for } \\
\text { Procurement Specification W-030-P5 identifies } \\
\text { differential pressures of } 15 \mathrm{psi}(100 \mathrm{kPa}) \text { or greater as } \\
\text { requiring bag changed-out. }\end{array}$ \\
\hline
\end{tabular}




\begin{tabular}{|c|c|}
\hline PDAH-AY2K1-1 & $\begin{array}{l}\text { AY-102 TANK INLET FILTERS - DIFFERENTIAL PRESSURE } \\
(H-2-826412 \text {, sh 1) } \\
\text { This is a Discrete Input (DI) alarm. } \\
\text { Alarm High: } 3 \text { inches (H20) } \\
\text { Alarm Set Point Basis: See instrument PDAH-AY1K1-1. }\end{array}$ \\
\hline PDAH-AY2WF-2 & $\begin{array}{l}\text { AY-102 TOWER BAG FILTER DIFFERENTIAL PRESSURE } \\
\text { This is a Discrete Input (DI) alarm. } \\
\text { Alarm High: } 15 \text { psi } \\
\text { Alarm Set Point Basis: See instrument PDAH-AYIWF-2. }\end{array}$ \\
\hline PDAH-AZ1K1-1 & $\begin{array}{l}\text { AZ-101 TANK INLET FILTERS - DIFFERENTIAL PRESSURE } \\
\text { (H-2-826412, Sh 1) } \\
\text { This is a Discrete Input (DI) aTarm. } \\
\text { Alarm High: } 3 \text { inches (H20) } \\
\text { Alarm Set Point Basis: See instrument PDAH-AY1K1-1. }\end{array}$ \\
\hline PDAH-AZ1WF-2 & $\begin{array}{l}\text { AZ-101 TOWER BAG FILTER DIFFERENTIAL PRESSURE } \\
\text { This is a Discrete Input (DI) alarm. } \\
\text { Alarm High: } 15 \text { psi } \\
\text { Alarm Set Point Basis: See instrument PDAH-AY1WF-2. }\end{array}$ \\
\hline PDAH-AZ2K $1-1$ & $\begin{array}{l}\text { AZ-102 TANK INLET FILTERS - DIFFERENTIAL PRESSURE } \\
(\mathrm{H}-2-826412, \text { sh } 1) \\
\text { This is a Discrete Input (DI) alarm. } \\
\text { Alarm High: } 3 \text { inches(H20) } \\
\text { Alarm Set Point Basis: See instrument PDAH-AY1K1-1. }\end{array}$ \\
\hline PDAH-AZ2WF-2 & $\begin{array}{l}\text { AZ-102 TOWER BAG FILTER DIFFERENTIAL PRESSURE } \\
\text { This is a Discrete Input (DI) alarm. } \\
\text { Alarm High: } 15 \text { psi } \\
\text { Alarm Set Point Basis: See instrument PDAH-AYIWF-2. }\end{array}$ \\
\hline
\end{tabular}




\begin{tabular}{|c|c|}
\hline PDI-702K2-2 & $\begin{array}{l}\text { FILTER ROOM A - PRESSURE (H-2-826383, sh 1; H-2-826455, Sh 1; } \\
\text { H-2-826455, sh 2) } \\
\text { Alarm Low : }-0.20 \text { inches(H2O) } \\
\text { Alarm Set Point Basis: Design pressure for the Zone II } \\
\text { type room is }-0.25 \text { inch(H20). Pressure should not } \\
\text { approach pressures of Zone IV rooms (which while near } \\
\text { atmospheric pressure could vary between }+0.05 \text { and }-0.10 \\
\text { inch }(\mathrm{H} 20) \text {. Refer to Logic Diagram Y035. }\end{array}$ \\
\hline PDI-702K2-3 & $\begin{array}{l}\text { FILTER ROOM B - PRESSURE }(H-2-826383 \text {, Sh 1) } \\
\text { See also Logic Diagram Y-035, } \\
\text { Alarm Low : }-0.20 \text { inches }(H 20) \\
\text { Alarm Set Point Basis: See instrument PDI-702K2-2. }\end{array}$ \\
\hline PDI-702-K2-7 & $\begin{array}{l}\text { ROOM DIFFERENTIAL PRESSURE - FILTER ROOMS TO CELL } \\
\text { (H-2-826383, sh 1) } \\
\text { This is a virtual analog (VA) alarm derived internal to } \\
\text { the MICON. } \\
\text { Alarm High: }-0.10 \text { inch }(H 20) \\
\text { Low : Eliminated } \\
\text { Alarm Set Point Basis: The purpose of the room } \\
\text { differential alarms is to indicate a potential back flow } \\
\text { of contaminated air into the filter rooms. The cel1 is } \\
\text { Zone I type room; the filter rooms A and B are Zone II } \\
\text { rooms. Refer to Design Guide for Department of Energy } \\
\text { Nuclear Facilities, published by ASHRAE. The cel1 may } \\
\text { range from -1.40 to -1.60 inch(H20) (see instrument PDI- } \\
\text { 702-K3-1). However during upset conditions (such as when } \\
\text { doors are open), the ventilation system maybe slow to } \\
\text { react. In addition, delays are included for PDI-702-K3- } \\
\text { l, PDI-702-K2-2 and PDI-702-K2-3 so that nuisance alarms } \\
\text { do not occur during anticipated upset conditions. The } \\
\text { value for the room differential alarm based on an assumed } \\
\text { instrument error of 0.04 inch(H20); the additional } 0.06 \\
\text { inch(H20) allows a marin of safety and early indication. } \\
\text { Refer to Logic Diagram Yo35. }\end{array}$ \\
\hline
\end{tabular}




\begin{tabular}{|c|c|}
\hline PDI-702K2-8 & $\begin{array}{l}\text { ROOM DIFFERENTIAL PRESSURE - STACK MONITOR ROOM TO FILTER } \\
\text { ROOMS(H-2-826383, Sh 1; H-2-826455, Sh 1) } \\
\text { This is a virtual analog (VA) alarm derived internal to } \\
\text { the MICON. } \\
\text { Alarm High: - } 0: 10 \text { inch (H20) } \\
\text { Low : El iminated } \\
\text { Alarm Set Point Basis: The purpose of the room } \\
\text { differential alarms is to indicate a potential back flow } \\
\text { of contaminated air from the filter room to the stack } \\
\text { monitor room/insrument room/environment. The filter } \\
\text { rooms A and B are Zone II rooms; the stack monitor is a } \\
\text { Zone IV rooms. Refer to Design Guide for Department of } \\
\text { Energy Nuclear Facilities, publ ished by ASHRAE. The } \\
\text { filter rooms may range from -0.20 to -0.30 inch(H20) (see } \\
\text { instrument PDI-702-K3-2 and PDI-702-K3-3). However } \\
\text { during upset conditions (such as when doors are open), } \\
\text { the ventilation system maybe sTow to react. In addition, } \\
\text { delays are included for PDI-702-K2-2 and PDI-702-K2-3 so } \\
\text { that nuisance alarms do not occur during anticipated } \\
\text { upset conditions. The value for the room differentiat } \\
\text { alarm based on an assumed instrument error of 0.04 } \\
\text { inch(H20); the additional o.06 inch(H20) allows a marin } \\
\text { of safety and early indication. Refer to Logic Diagram } \\
\text { yo35. }\end{array}$ \\
\hline PDI-702K24-1 & $\begin{array}{l}\text { ZONAL HEPA FILTER, ROOM A (HEPA AZ702-K2-4-1) } \\
\text { (H-2-826383, sh 1) } \\
\text { Alarm High: } 0.60 \text { inch(H20) } \\
\text { Alarm Set Point Basis: HEPA filter between the cell and } \\
\text { the filter rooms is rated at } 1000 \text { SCFM, but is operated } \\
\text { at only } 200 \text { SCFM by design. Therefore, the HEPA filter } \\
\text { is sized to produce an approximate, maximum } 0.20 \\
\text { inch (H20) pressure drop when clean. For the primary } \\
\text { ventilation system (1000 SCFM), the high differential } \\
\text { pressure alarms annunciates at } 3.0 \text { inch (H20). (see } \\
\text { instrument PDI-AZ-K14-1A, -1B, } 2 A \text {, and } 2 B) \text { or } 3 \text { times } \\
\text { the initial maximum rating of } 1.0 \text { inch(H20). For the } \\
\text { zonal filter, } 3 \text { times the initial rating equates to } 0.60 \\
\text { inch(H20). This value also accommodates the control } \\
\text { valve's differential pressure. And, since the difference } \\
\text { in pressure between the cell and the filter room is } \\
\text { determined in part by the HEPA filter, the maximum } \\
\text { allowable differential pressure across the filter does } \\
\text { not exceed the maximum allowable difference in the } \\
\text { pressures of the rooms. Refer to instrument PDI-702K2-7. } \\
\text { Also refer to Logic Diagram Y035. }\end{array}$ \\
\hline
\end{tabular}




\begin{tabular}{|c|c|}
\hline PDI-702K24-2 & $\begin{array}{l}\text { ZONAL HEPA FILTER, ROOM B (HEPA AZ702-K2-4-2) } \\
\text { (H-2-826383, sh 1) } \\
\text { Alarm High: } 0.60 \text { inch }(H 20) \\
\text { See also Logic Diagram } \mathrm{Y}-035 . \\
\text { Alarm Set Point Basis: See instrument PDI-702K24-1. }\end{array}$ \\
\hline PDI-702K3-1 & $\begin{array}{l}\text { PRIMARY VENT CELL - PRESSURE(H-2-826384, Sh 1) } \\
\text { Alarm Low: - } 1.40 \text { inch (H20) } \\
\text { Alarm Set point Basis: Design pressure for the Zone I } \\
\text { type room is }-1.50 \text { inch(H20). Pressure should remain } \\
\text { below pressure of Filter Rooms A and B. Pressure should } \\
\text { coincide with differential: pressure alarm between the } \\
\text { cell and filter rooms (refer to instrument PDI-702K2-7). } \\
\text { Also refer to Logic Diagram Y035. }\end{array}$ \\
\hline PDI-702K33-1A & 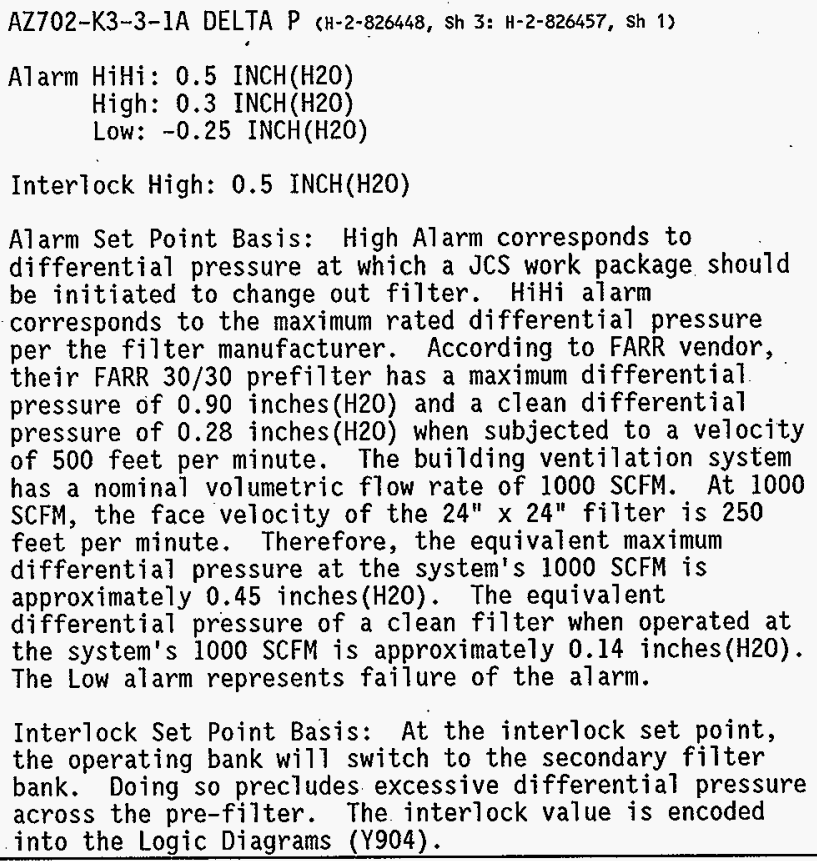 \\
\hline
\end{tabular}


HNF-1529, Rev 2

\begin{tabular}{|c|c|}
\hline PDI-702K33-1B & $\begin{array}{l}\text { AZ702-K3-3-1B DELTA P }\langle\mathrm{H}-2-826457 \text {, sh 1) } \\
\text { Alarm HiHi: } 0.5 \text { INCH(H2O) } \\
\text { High: } 0.3 \text { INCH(H2O) } \\
\text { LOW: }-0.25 \mathrm{INCH}(\mathrm{H} 20) \\
\text { Interlock High: } 0.5 \mathrm{INCH}(\mathrm{H} 20) \\
\text { Alarm Set Point Basis: See instrument PDI-702-K33-1A. } \\
\text { Interlock Set Point Basis: See instrument PDI-702-K33- } \\
\text { IA. }\end{array}$ \\
\hline
\end{tabular}




\begin{tabular}{|c|c|}
\hline PDI-702K34-1A & 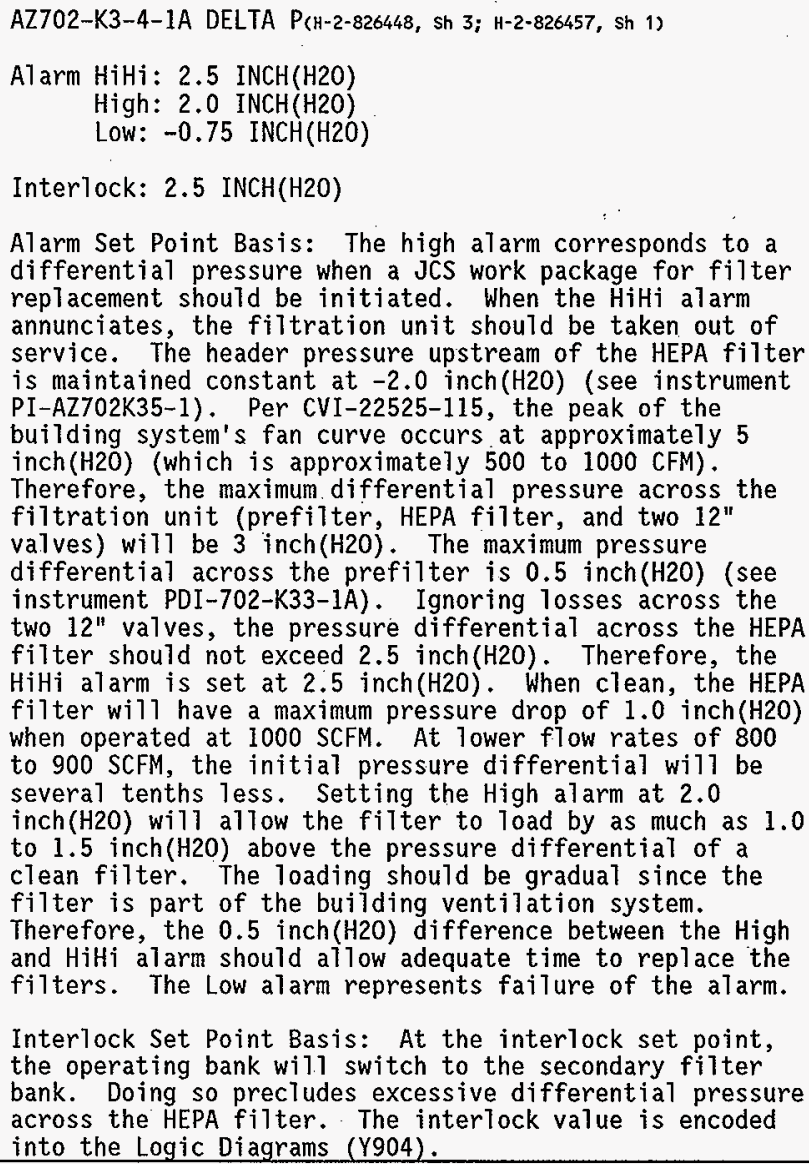 \\
\hline PDI -702K34-1B & $\begin{array}{l}\text { AZ702-K3-4-1B DELTA P.(H-2-826457, sh 1) } \\
\text { Alarm HiHi: } 2.5 \operatorname{INCH}\left(\mathrm{H}_{2} \mathrm{O}\right) \\
\text { High: } 2.0 \mathrm{INCH}(\mathrm{H} 2 \mathrm{O}) \\
\text { Low: }-0.75 \operatorname{INCH}(\mathrm{H} 2 \mathrm{O}) \\
\text { Interlock: } 2.5 \mathrm{INCH}(\mathrm{H} 20) \\
\text { Alarm Set Point Basis: See instrument PDI-702-K34-1A. } \\
\text { Interlock Set Point Basis: See instrument PDI-702-K34- } \\
\text { 1A. }\end{array}$ \\
\hline
\end{tabular}




\begin{tabular}{|c|c|}
\hline PDI-AYIK45-1 & $\begin{array}{l}\text { AY101 RECIRCULATION FAN OP } \\
\text { Alarm High: } 24.0 \text { INCH(H20) } \\
\text { Alarm Set Point Basis: By way of the pump's performance } \\
\text { curves, the high alarm should correspond to the minimum } \\
\text { flow rate through the recirculation loop. Insufficient } \\
\text { vendor information is available to accurately determine } \\
\text { the value. The set point is initially being taken as the } \\
\text { maximum instrument range minus the approximate instrument } \\
\text { deadband. Set point should be adjusted based on } \\
\text { operational experience. }\end{array}$ \\
\hline PDI-AY1K48-1 & $\begin{array}{l}\text { AY101-K4-8-1 (CONDENSER) DELTA P(H-2-826414, sh 2) } \\
\text { Alarm High: } 11.0 \text { INCH(H20) } \\
\text { Interlock Low: } 2 \text { INCH(H20) } \\
\text { Alarm Set Point Basis: Procurement Specification W-030- } \\
\text { P14 del ineates a maximum pressure differential across the } \\
\text { shel1 side of the heat exchanger as } 0.4 \text { psi. Converting } \\
0.4 \text { psi to inches(h20) yields approximately } 11 \\
\text { inches(H20). The flow rate corresponding to the } 0.4 \text { psi } \\
\text { differentiai was verified to be within 5\% of the fiow } \\
\text { rate described in the KEH Process System Description } \\
\text { document. } \\
\text { Interlock Set Point Basis: A differential pressure of } \\
\text { less than the set point indicates little or no flow } \\
\text { through the recirculation loop. The fan will turn off } \\
\text { should the differential pressure across the shell side of } \\
\text { the condenser drop below the set point. The interlock } \\
\text { set point is encoded into Logic Diagram Y204. See also } \\
\text { Logic Diagram Y-200. }\end{array}$ \\
\hline PDI-AY2K45-1 & $\begin{array}{l}\text { AY102 RECIRCULATION FAN DP } \\
\text { Alarm High: } 24.0 \text { INCH(H20) } \\
\text { Alarm Set Point Basis: See instrument PDI-AY1-K45-1. }\end{array}$ \\
\hline PDI-AY2K48-I & $\begin{array}{l}\text { AY102-K4-8-1 (CONDENSER) DELTA P(H-2-826415, sh 2), } \\
\text { Alarm High: } 11.0 \text { INCH(H2O) } \\
\text { Interlock Low: } 2 \text { INCHS(H2O) } \\
\text { Alarm Set Point Basis: See instrument PDI-AY1-K48-1. } \\
\text { Even though AZ-101 has a larger heat load, the basis was } \\
\text { verified as still valid. } \\
\text { See also Logic Diagram Y-202. } \\
\text { Interlock Set Point Basis: See instrument PDI-AYl-K48-1. }\end{array}$ \\
\hline
\end{tabular}




\begin{tabular}{|c|c|}
\hline PDI-AZK14-1A & $\begin{array}{l}\text { AZ-K1-4-1A DELTA P(H-2-826370, Sh 1) } \\
\text { Alarm Hihi: } 5.0 \text { INCH(H20) } \\
\text { Hi: } 3.0 \text { INCH(H2O) } \\
\text { LOW: }-0.75 \text { INCH(H2O) } \\
\text { Interlock: } 5.0 \text { INCH(H20) } \\
\text { Alarm Set Point Basis: The high alarm corresponds to a } \\
\text { differential pressure when a JCS work package for filter } \\
\text { replacement should be initiated (this differential value } \\
\text { is based on operating experience with other Tank Farm } \\
\text { ventilation systems). When the HiHi alarm annunciates, } \\
\text { the filtration unit should be taken out of service. The } \\
\text { initial maximum rating of a clean filter is } 1.0 \text { inch (H20) } \\
\text { (reference, Flander's catalog). The High alarm } \\
\text { corresponds to } 3 \text { times the initial maximum rating. The } \\
\text { interlock (5.0 IN H2O) corresponds to the logic value } \\
\text { used in initiating a filter bank switchover (reference } \\
\text { Logic Diagram Yoo3). Both the High Alarm set point and } \\
\text { the interlock are bounded by Flander's rated limit of } 10 \\
\text { inches (H20) (reference, Flander's catalog). The Low } \\
\text { alarm represents failure of the alarm. }\end{array}$ \\
\hline PDI-AZK14-1B & $\begin{array}{l}\text { AZ-K1-4-1B DELTA P } \\
\text { A1 arm Hihi: } 5.0 \text { INCH(H2O) } \\
\text { Hi: } 3.0 \text { INCH(H20) } \\
\text { Low: }-0.75 \text { INCH(H2O) } \\
\text { Interlock: } 5.0 \text { INCH(H2O) } \\
\text { Alarm Set Point Basis: See instrument PDI-K14-1A. }\end{array}$ \\
\hline PDI-AZK14-2A & $\begin{array}{l}\text { AZ-K1-4-2A DELTA P (H-2-826370, sh1) } \\
\text { Alarm Hihi: } 5.0 \text { INCH(H2O) } \\
\text { Hi: } 3.0 \text { INCH }(\mathrm{H} 20) \\
\text { Low: }-0.75 \text { INCH(H20) } \\
\text { Interlock: } 5.0 \text { INCH(H20) } \\
\text { Alarm Set Point Basis: See instrument PDI-K14-1A. }\end{array}$ \\
\hline PDI-AZK14-2B & $\begin{array}{l}\text { AZ-K1-4-2B DELTA P } \\
\text { Alarm Hihi: } 5.0 \operatorname{INCH(H2O)} \\
\text { Hi: } 3.0 \operatorname{INCH}(\mathrm{H} 20) \\
\text { Low: }-0.75 \operatorname{INCH}(\mathrm{H} 20) \\
\text { Interlock: } 5.0 \mathrm{INCH}(\mathrm{H} 20) \\
\text { Alarm Set Point Basis: See instrument PDI-K14-1A. }\end{array}$ \\
\hline
\end{tabular}




\begin{tabular}{|c|c|}
\hline PDI-AZK18-1 & $\begin{array}{l}\text { AZ-K1-8-1 VAPOR DELTA P } \\
\text { Alarm High: } 11.0 \text { INCH(H20) } \\
\text { Low: }-2.50 \text { INCH(H2O) } \\
\text { Procurement Specification W-030-P14 delineates a maximum } \\
\text { pressure differential across the shel1 side of the heat } \\
\text { exchanger as } 0.4 \text { psi. Converting } 0.4 \text { psi to inches(h20) } \\
\text { yields approximately } 11 \text { inches(H20). The flow rate } \\
\text { corresponding to the } 0.4 \text { psi differential was verified to } \\
\text { be within } 5 \% \text { of the flow rate described in the KEH } \\
\text { Process System Description document. The Low alarm } \\
\text { represents failure of the alarm. }\end{array}$ \\
\hline PDI-AZK19-1 & $\begin{array}{l}\text { AZ-K1-9-1 VAPOR DELTA P(H-2-826378, Sh 2) } \\
\text { Alarm Hihi: } 15.0 \text { INCH(H2O) } \\
\text { Hi: } 10.0 \text { INCH }(\mathrm{H} 20) \\
\text { Low: }-1.25 \text { INCH(H2O) } \\
\text { See also Logic Diagram Y-017. } \\
\text { Alarm Set Point Basis: The pressure drop across the HEME } \\
\text { is initially } 9.0 \text { to } 11.0 \text { inches w.g. at } 1,000 \text { scfm when } \\
\text { the HEME is clean and saturated. The HEME can tolerate } \\
\text { higher differential pressures without damage to the } \\
\text { filter media; the maximum allowed pressure drop for the } \\
\text { filter is } 20 \text { inches w.g. Therefore, a pressure drop of } \\
\text { 15 inches w.g. was selected as the upper limit allowed } \\
\text { for operation when the HEME is dirty. The operating } \\
\text { range of the instrumentation is } 0 \text { to } 20 \text { inches w.g. } \\
\text { The low alarm represents alarm failure. }\end{array}$ \\
\hline
\end{tabular}




\begin{tabular}{|c|c|}
\hline PDI-AZRWF-I & $\begin{array}{l}\text { AZ-RW-F-1 DELTA P } \\
\text { Al.arm High: } 9.0 \text { PSID } \\
\text { Low: }-1.25 \text { INCH(H20) } \\
\text { Alarm Set Point Basis: High Alarm should correspond to } \\
\text { maximum operating pressure of the strainer. KEH Design } \\
\text { suggests } 9.0 \text { psid. The low alarm represents alarm } \\
\text { failure. }\end{array}$ \\
\hline PDI-AZ1K45-1 & $\begin{array}{l}\text { AZ101 RECIRCULATION FAN DP } \\
\text { Alarm High: } 24.0 \text { INCH(H20) } \\
\text { Alarm Set Point Basis: See instrument PDI-AY1-K45-1. }\end{array}$ \\
\hline PDI-AZIK48-1 & $\begin{array}{l}\text { AZ101-K4-8-1 (CONDENSER) DELTA P(H-2-826416, sh 2) } \\
\text { Alarm High: } 11.0 \text { INCH }(\mathrm{H} 20) \\
\quad \text { Low: } 2.0 \text { INCH }(\mathrm{H} 20) \\
\text { See also Logic Diagram Y-204. } \\
\text { Alarm Set Point Basis: See instrument PDI-AY1-K48-1. } \\
\text { Interlock Set Point Basis: See instrument PDI-AY1-K48-1. }\end{array}$ \\
\hline PDI-AZ2K45-1 & $\begin{array}{l}\text { AZ102 RECIRCULATION FAN DP } \\
\text { Alarm High: } 24.0 \text { INCH(H20) } \\
\text { Alarm Set Point Basis: See instrument PDI-AY1-K45-1. }\end{array}$ \\
\hline PDI-AZ2K48-1 & $\begin{array}{l}\text { AZ102-K4-8-1 (CONDENSER) DELTA P(H-2-826417, Sh 2) } \\
\text { Alarm High: } 11.0 \text { INCH(H2O) } \\
\text { Alarm Low: } 2.0 \text { INCH(H2O) } \\
\text { See also Logic Diagram Y-206. } \\
\text { Alarm Set Point Basis: See instrument PDI-AY1-K48-1. } \\
\text { Interlock Set Point Basis: See instrument PDI-AY1-K48-1. }\end{array}$ \\
\hline
\end{tabular}




\begin{tabular}{|c|c|}
\hline PDI-AZK110-1A & $\begin{array}{l}\text { AZ-K1-10-1A DELTA P } \\
\text { Alarm HiHi: } 3.00 \text { INCH(H20) } \\
\text { Alarm High: } 2.50 \text { INCH(H2O) } \\
\text { Alarm Low: }-0.63 \text { INCH(H2O) } \\
\text { Alarm Set Point Basis: Flanders absorbers have an } \\
\text { initial pressure drop of } 1.25 \text { inches w.g. when operated } \\
\text { at } 1,000 \text { cfm. The differential pressure will not } \\
\text { increase as the HEGA absorbs non-condensable gases, } \\
\text { However, the differential pressure will increase as the } \\
\text { HEGA absorbs moisture. Although the maximum structural } \\
\text { design } 1 \text { imit for a HEGA is lo inches w.g. a limit of } 3.0 \\
\text { in w.g. was selected to provide an adequate capacity for } \\
\text { moisture absorption should the chilled water condenser or } \\
\text { electric heater become inoperative. } \\
\text { Since the HEGA is downstream of a HEPA.filter, any } \\
\text { increase in resistance will indicate failure of the } \\
\text { upstream HEPA filter. The High alarm indicates a } \\
\text { potential problem is occurring with the HEGA filter. } \\
\text { When the High alarm occurs, the operators should switch } \\
\text { operation to the standby train. The HiHi alarm indicates } \\
\text { the filter's loading is increasing and the filter should } \\
\text { be taken out-of-service. The HiHi set point is the same } \\
\text { as the OSD limit of allowable HEGA differential pressure. } \\
\text { The HiHi alarm corresponds to the logic value used in } \\
\text { initiating a filter bank switchover (reference Logic } \\
\text { Diagrams Y003 and Y108). The Low alarm represents alarm } \\
\text { failure. }\end{array}$ \\
\hline PDI-AZK110-IB & $\begin{array}{l}\text { AZ-K1-10-1B DELTA P } \\
\text { Alarm HiHi: } 3.00 \text { INCH }(\mathrm{H} 20) \\
\text { Alarm High: } 2.50 \text { INCH }(\mathrm{H} 20) \\
\text { Alarm Low: }-0.63 \text { INCH }(\mathrm{H} 20) \\
\text { Alarm Set Point Basis: See instrument PDI-AZK110-1A. }\end{array}$ \\
\hline PI-AY1K1-1 & $\begin{array}{l}\text { TK-AY-101 PRESSURE(H-2-826394, sh 1; H-2-826407, Sh 1; TMACS-702-3) } \\
\text { Alarm HiHi: }-0.05 \text { INCH }(H 20) \\
\text { High: }-0.50 \text { INCH }(H 2 O) \\
\text { Low : }-3.50 \text { INCH }(H 2 O) \\
\text { LoLo: }-4.00 \text { INCH }(H 2 O) \\
\text { Alarm Set Point Basis: HiHi and LoLo alarms are } \\
\text { incorporated to maintain tank pressure between } 0.0 \\
\text { and -4.0 INCH }(\mathrm{H} 20) \text {. Refer to Logic Diagram Y097. }\end{array}$ \\
\hline
\end{tabular}




\begin{tabular}{|c|c|}
\hline PI-AY2K1-1 & 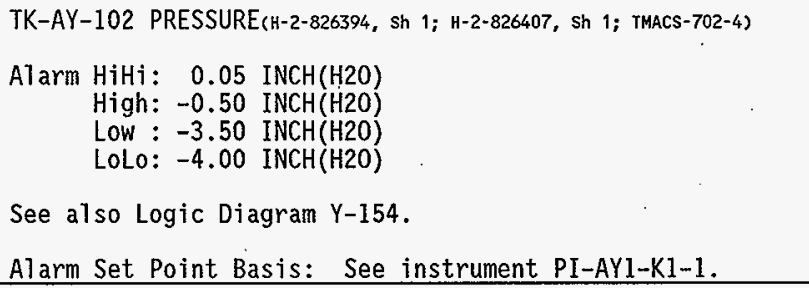 \\
\hline PI-AZK1-1A & 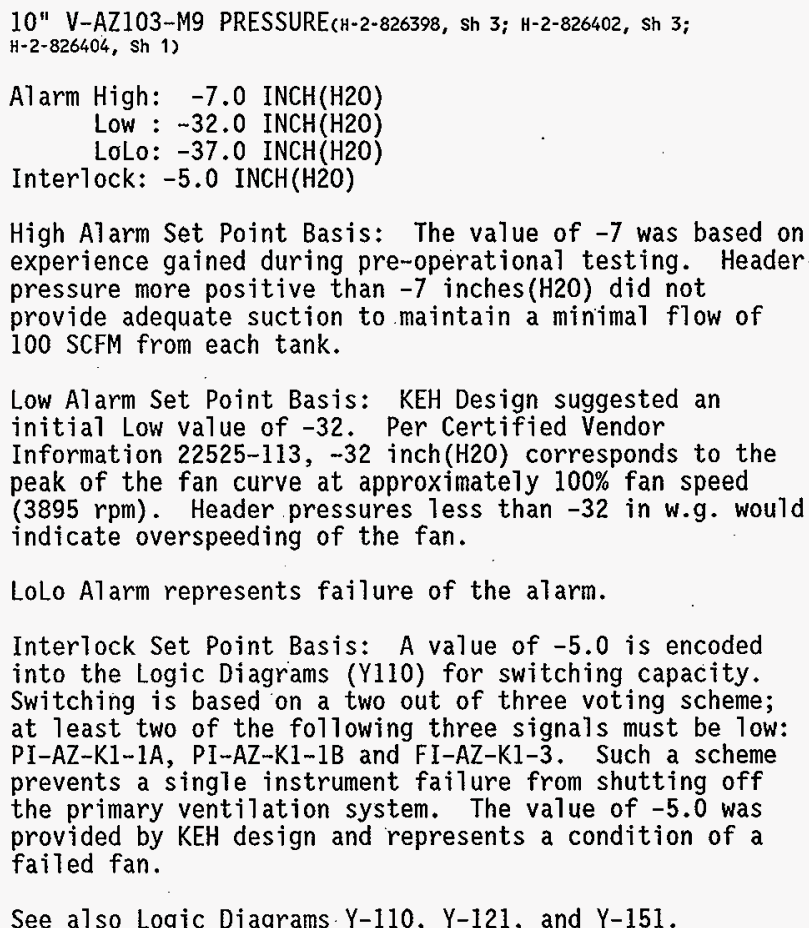 \\
\hline
\end{tabular}




\begin{tabular}{|c|c|}
\hline PI-AZK1-1B & 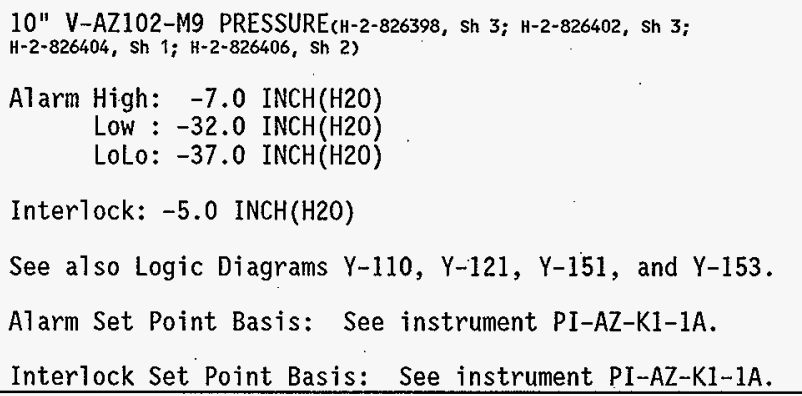 \\
\hline PI-AZRW-1 & $\begin{array}{l}\text { 2" RW-AZ401-M5 PRESSURE } \\
\text { A1 arm Low : } 20.0 \text { PSI } \\
\text { A1 arm Set-Point Basis: Line pressure is reduced to } 50 \\
\text { psig by PCV-AZRW-1. Pressure in 2"RW-AZ401-M5 should } \\
\text { remain. high enough to adequately fi11 towers (especially) } \\
\text { when conductivity probe opens drain } 7 \text { ine). For normal } \\
\text { operation, water feed pressure to cooling towers should } \\
\text { be } 15 \text { to } 50 \text { psig. Note, that there will be pressure loss } \\
\text { due to piping and valving between gauge PI-AZ-RW-1 and } \\
\text { towers. Pressure loss is. dependent upon flow rate to } \\
\text { towers. }\end{array}$ \\
\hline PI-AZIKI-1 & $\begin{array}{l}\text { TK-AZ-101 PRESSURE(K-2-826394, sh 2; rmACS-702-8) } \\
\text { Alarm HiHi: }-0.05 \text { INCH(H2O) } \\
\text { High: }-0.50 \text { INCH }(\mathrm{H} 2 \mathrm{O}) \\
\text { Low: }-3: 50 \text { INCH }(\mathrm{H} 2 \mathrm{O}) \\
\text { LoLo: }-4.00 \text { INCH(H2O) } \\
\text { Alarm Set Point Basis: See instrument PI-AY1-K1-1. }\end{array}$ \\
\hline PI-AZ2-K1-1 & $\begin{array}{l}\text { TK-AZ-102 PRESSURE }(\mathrm{H}-2-826394 \text {, Sh 2; TMACS-702-9) } \\
\text { Alarm HiHi: }-0.05 \text { INCH(H2O) } \\
\text { High: }-0.50 \text { INCH }(\mathrm{H} 20) \\
\text { LOW }-3.50 \text { INCH }(\mathrm{H} 20) \\
\text { LoLo: }-4.00 \text { INCH(H2O) } \\
\text { ATarm Set Point Basis: See instrument PI-AY1-K1-1. }\end{array}$ \\
\hline
\end{tabular}




\begin{tabular}{|c|c|}
\hline PI-AZ702K35-1 & 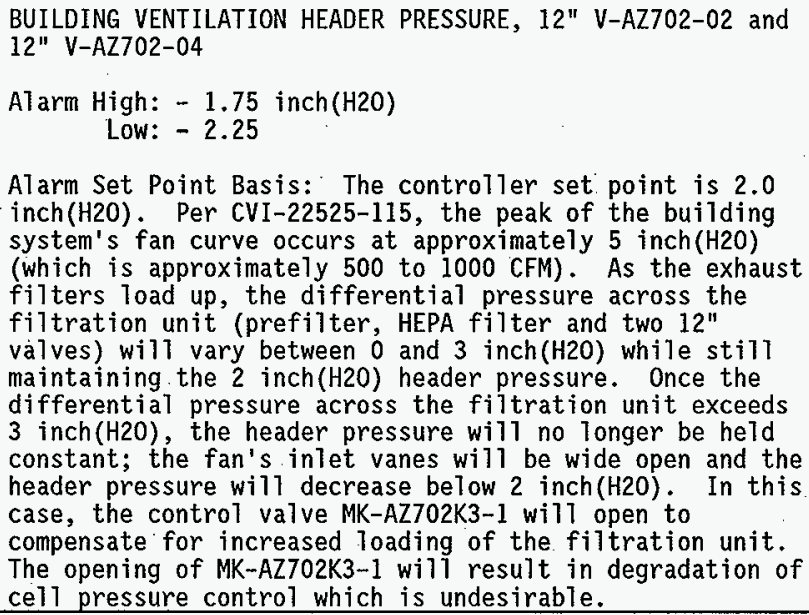 \\
\hline $\begin{array}{l}\text { RAH-AZK19-1 } \\
\text { (Note that } \\
\text { H-2-826381, Sh 3, } \\
\text { calls out th is tag } \\
\text { number as } \\
\text { RI-AZK19-1A) }\end{array}$ & $\begin{array}{l}\text { HEME/CELL RAD LEVEL ALARM(H-2-826381, Sh 3) } \\
\text { This is a Discrete Input (DI) alarm. } \\
\text { See also Logic Diagram Y-024. } \\
\text { Alarm High: } 300 \mathrm{mrem} / \mathrm{hr} \\
\text { Alarm Set Point Basis: The setpoint is based on the } \\
\text { HNF-IP-1266, Section } 5.18 . \text { C. } 1 . \text { a limit of } 300 \mathrm{mrem} / \mathrm{hr} \\
\text { reading on a hand held instrument at the 10cation of the } \\
\text { canning plate of the detector tube for the HEME Gamma } \\
\text { monitor. }\end{array}$ \\
\hline RAH-702K3-1 & 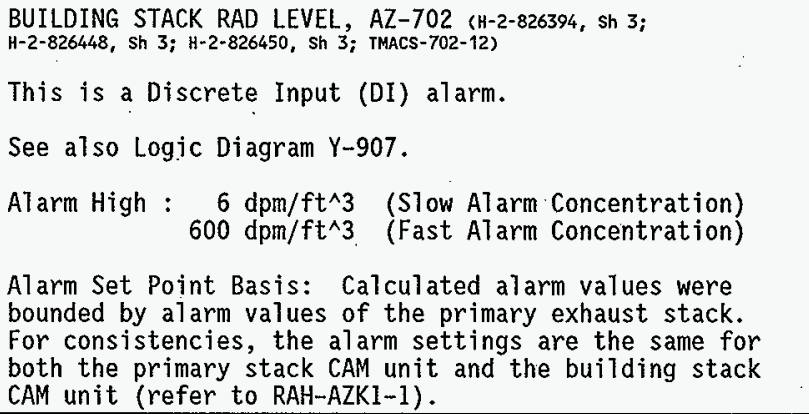 \\
\hline
\end{tabular}




\begin{tabular}{|c|c|}
\hline $\begin{array}{l}\text { RAH-AZK1-1 } \\
\text { This tag number was } \\
\text { formerly calted } \\
\text { RIAS-AZK1-1. }\end{array}$ & 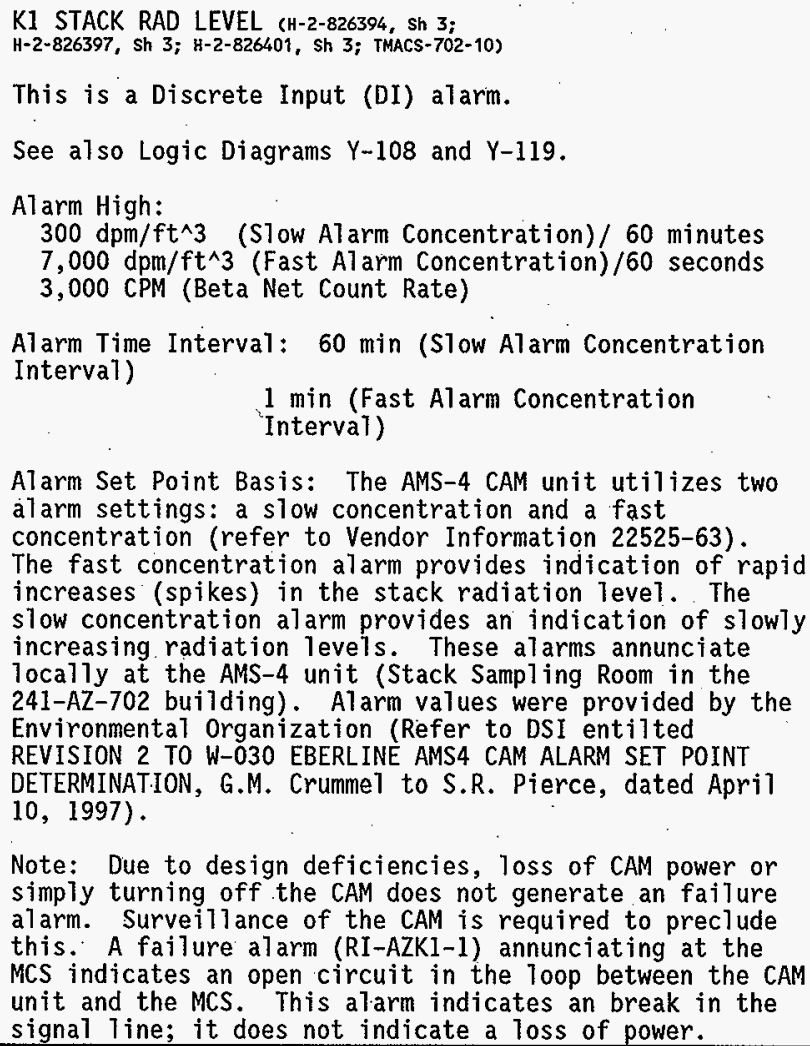 \\
\hline TAL-AY1K12-1 & $\begin{array}{l}\text { AY-101 TANK INLET FILTERS - TEMPERATURE ALARM } \\
(H-2-826412, \text { Sh 1) } \\
\text { This is a Discrete Input (DI) alarm. } \\
\text { Alarm Low : } 35 \text { degrees Fahrenheit } \\
\text { Alarm Set Point Basis: Inlet heaters prevent frost from } \\
\text { developing on the tank's inlet filters. The heater's } \\
\text { controller activates at } 40 \text { degrees Fahrenheit (refer to } \\
\text { instrument TIC-AY101k102-1). The alarm is set below the } \\
\text { controller's set point but above the freezing point of } \\
\text { water. }\end{array}$ \\
\hline
\end{tabular}




\begin{tabular}{||l|l||}
\hline TAL-AY2K12-1 & $\begin{array}{l}\text { AY-102 TANK INLET FILTERS - TEMPERATURE ALARM } \\
\text { (H-2-826412, sh 1) } \\
\text { This is a Discrete Input (DI) alarm. } \\
\text { Alarm Low : 35 degrees Fahrenheit } \\
\text { Alarm Set Point Basis: See instrument TAL-AY1K12-1. }\end{array}$ \\
\hline TAL-AZ1K12-1 & $\begin{array}{l}\text { AZ-101 TANK INLET FILTERS - TEMPERATURE ALARM } \\
\text { (H-2-826412, sh 1) } \\
\text { This is a Discrete Input (DI) alarm. } \\
\text { A1arm Low : 35 degrees Fahrenheit } \\
\text { Alarm Set Point Basis: See instrument TAL-AY1K12-1. }\end{array}$ \\
\hline TAL-AZ2K12-1 & $\begin{array}{l}\text { AZ-102 TANK INLET FILTERS - TEMPERATURE ALARM } \\
\text { (H-2-826412, sh 1) } \\
\text { This is a Discrete Input (DI) alarm. } \\
\text { Alarm Low : 35 degrees Fahrenheit } \\
\text { Alarm Set Point Basis: See instrument TAL-AY1K12-1. }\end{array}$ \\
$\begin{array}{ll}\text { CONDENSER AZ-K1-8-1: AIRSTREAM OUTLET TEMPERATURE } \\
\text { This is a "10cal" (LOC) alarm. } \\
\text { Alarm Low : 38 degrees Fahrenheit } \\
\text { Alarm Lolo: 35 degrees Fahrenheit } \\
\text { Alarm Set Point Basis: Ice Bui1d-up could occur on the } \\
\text { condenser coils within the primary exhaust train. } \\
\text { Maintaining the condenser's airstream outlet temperature } \\
\text { above 35 F wi11 prevent water in the primary exhaust from } \\
\text { freezing. }\end{array}$ \\
\hline TAL-AZK18-1B
\end{tabular}




\begin{tabular}{|c|c|}
\hline TDIC-AZK12-1A & 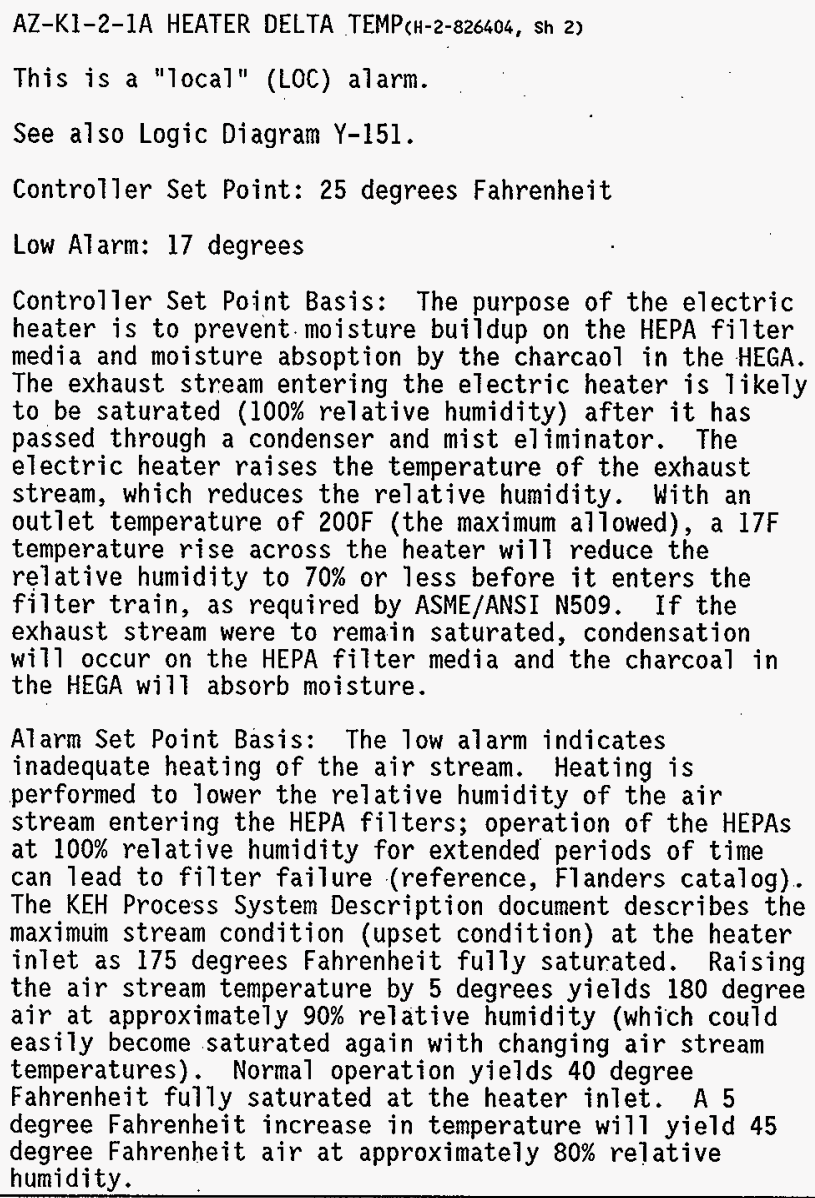 \\
\hline
\end{tabular}




\begin{tabular}{|c|c|}
\hline TDIC-AZ-K12-1B & $\begin{array}{l}\text { AZ-K1-2-1B HEATER DELTA TEMP(H-2-826406, sh 3) } \\
\text { This is a "10Ca1" (LOC) alarm. } \\
\text { Controller Set Point: } 25 \text { degrees Fahrenheit } \\
\text { Alarm Set Point: } 17 \text { degrees Fahrenheit } \\
\text { Controller Set Point Basis: See instrument TDIC-AZ-K12- } \\
\text { A. } \\
\text { Alarm Set Point Basis: See instrument TDIC-AZ-K12-1A. }\end{array}$ \\
\hline TI-702-K2-1 & $\begin{array}{l}\text { STACK MONITOR ROOM TEMP(H-2-826452, Sh 2) } \\
\text { ATarm HiHi: } 110 \text { DEG F } \\
\text { High: } 90 \text { DEG F } \\
\text { Low: }-41.25 \text { DEG F } \\
\text { See a1so Logic Diagram Y-912. } \\
\text { Alarm Set Point Basis: The logic diagram (Y912) } \\
\text { describes } 110 \text { degree Fahrenheit as the temperature at } \\
\text { which the wall dampers open allowing passive ventilation } \\
\text { of the room. The High Alarm is set below this value to } \\
\text { warn the operator of the impending action. The HiHi } \\
\text { Alarm is set at the activation temperature. The Low } \\
\text { alarm represents an instrument failure alarm. }\end{array}$ \\
\hline TI-702-K2-2 & $\begin{array}{l}\text { E/I ROOM A TEMP(H-2-826453, sh 2) } \\
\text { Alarm HiHi: } 110 \text { DEG F } \\
\quad \text { High: } 90 \text { DEG F } \\
\text { Low: }-41.25 \text { DEG F } \\
\text { See also Logic Diagram Y-913. } \\
\text { Alarm Set Point Basis: See instrument TI-702-K2-1. } \\
\text { Also, Procurement Specification W-030-P3 requires the K1- } \\
5-1 A \text { and K1-5-1B variable speed drives to be operable at } \\
\text { ambient temperatures of up to } 120 \text { degrees Fahrenheit. } \\
\text { The Low alarm represents an instrument failure alarm. }\end{array}$ \\
\hline $\mathrm{TI}-702-\mathrm{K} 2-3$ & $\begin{array}{l}\text { E/I ROOM B TEMP }(H-2-826454, \text { sh 2) } \\
\text { Alarm HiHi: } 110 \text { DEG F } \\
\text { High: } 90 \text { DEG F } \\
\quad \text { Low: }-41.25 \text { DEG F } \\
\text { See also Logic Diagram Y-914. } \\
\text { Alarm Set Point Basis: See instrument TI-702-K2-2. }\end{array}$ \\
\hline
\end{tabular}




\begin{tabular}{|c|c|}
\hline TI-702-K2-4 & $\begin{array}{l}\text { PV FLTR ROOM A TEMP } \\
\text { Alarm High: } 120 \text { DEG F } \\
\text { Low: }-41.25 \text { DEG F } \\
\text { Alarm Set Point Basis: Procurement Specification W-030- } \\
\text { P3 requires operation of the entire Air Clean-Up trains } \\
\text { (bought under that procurement specification) to operate } \\
\text { in temperatures up to } 140 \text { degrees Fahrenheit. The Low } \\
\text { alarm represents an instrument failure alarm. }\end{array}$ \\
\hline$T I-702-K 2-5$ & $\begin{array}{l}\text { PV FLTR ROOM B TEMP } \\
\text { Alarm High: } 120 \text { DEG F } \\
\text { Low: }-41.25 \mathrm{DEG} \mathrm{F} \\
\text { Alarm Set Point Basis: See instrument TI-702-K2-4. }\end{array}$ \\
\hline$T I-A Z-K 12-1 A$ & $\begin{array}{l}\text { AZ-K1-2-1A INLET TEMP(H-2-826404, sh 2) } \\
\text { Alarm High: } 175 \text { DEG F } \\
\text { Low: }-31.25 \text { DEG F } \\
\text { See also Logic Diagram Y-151. } \\
\text { Alarm Set Point Basis: The KEH Process System } \\
\text { Description identifies the maximum air stream conditions } \\
\text { at the heater's inlet as } 175 \text { degrees Fahrenheit with loss } \\
\text { of cooling. }\end{array}$ \\
\hline$T I-A Z-K 12-1 B$ & $\begin{array}{l}\text { AZ-K1-2-1B INLET TEMP(H-2-826406, sh 3) } \\
\text { Alarm High: } 175 \text { DEG F } \\
\quad \text { Low: }-31.25 \text { DEG F } \\
\text { See also Logic Diagram Y-153. } \\
\text { Alarm Set Point Basis: See instrument TI-AZ-K12-1A. }\end{array}$ \\
\hline
\end{tabular}




\begin{tabular}{|c|c|}
\hline TI-AZK12-3A & 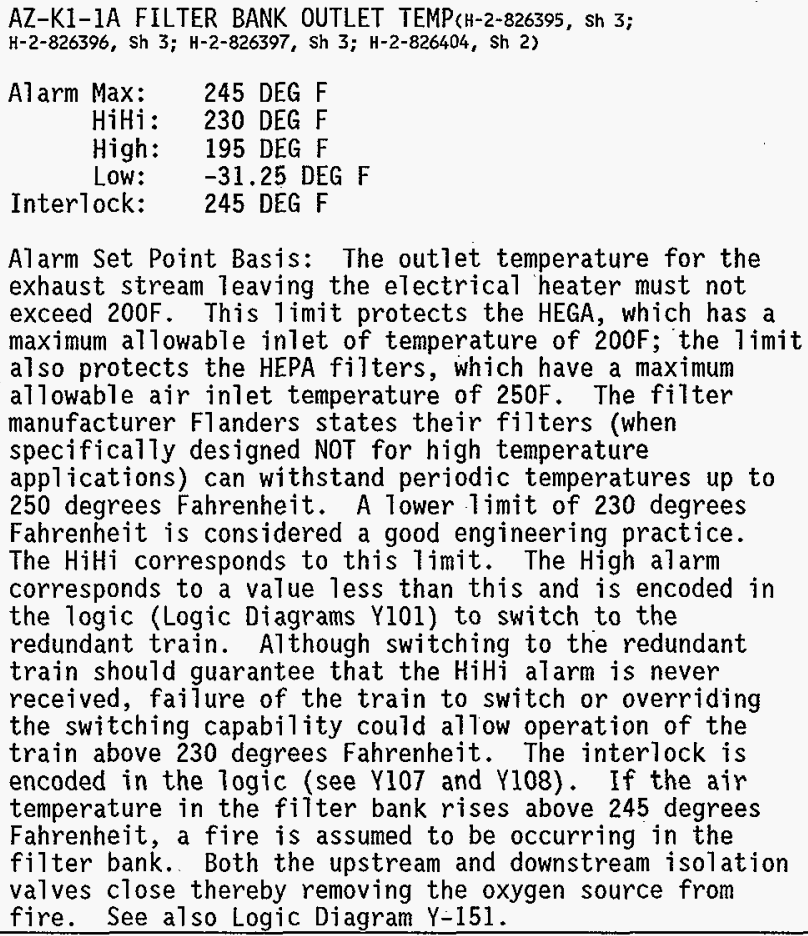 \\
\hline TI-AZK12-3B & 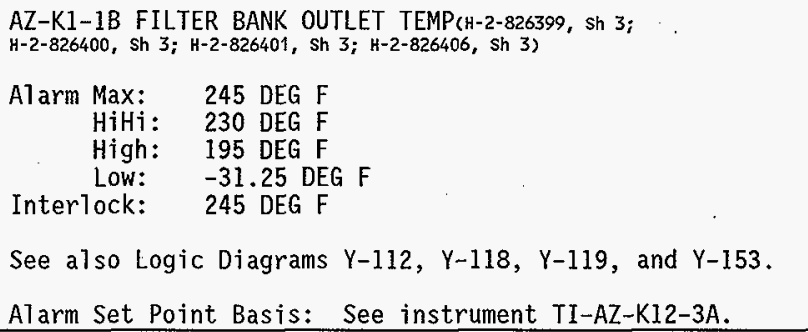 \\
\hline
\end{tabular}




\begin{tabular}{|c|c|}
\hline TIC-AYIK12-1 & $\begin{array}{l}\text { AY-101 TANK INLET FILTERS - TEMPERATURE CONTROLLER } \\
\text { This is a discrete (DI) alarm. } \\
\text { Controller Set Point: } 40 \text { degrees Fahrenheit } \\
\text { Controller Set Point Basis: Inlet heaters prevent frost } \\
\text { from developing on the tank's inlet filters. The } \\
\text { heater's controller activates at a temperature above } \\
\text { which frost is likely to occur. See also instrument TAL- } \\
\text { AYK12-1. }\end{array}$ \\
\hline TIC-AY2K12-1 & $\begin{array}{l}\text { AY-102 TANK INLET FILTERS - TEMPERATURE CONTROLLER } \\
\text { This is a discrete (DI) alarm. } \\
\text { Controller Set Point: } 40 \text { degrees Fahrenheit } \\
\text { Controller Set Point Basis: See instrument TIC- } \\
\text { AY101K102-1. }\end{array}$ \\
\hline TIC-AZIK12-1 & $\begin{array}{l}\text { AZ-101 TANK INLET FILTERS - TEMPERATURE CONTROLLER } \\
\text { This is a discrete (DI) a]arm. } \\
\text { Controller Set Point: } 40 \text { degrees Fahrenheit } \\
\text { Controller Set Point Basis: See instrument TIC- } \\
\text { AY101k102-1. }\end{array}$ \\
\hline TIC-AZ2K12-1 & $\begin{array}{l}\text { AZ-102 TANK INLET FILTERS - TEMPERATURE CONTROLLER } \\
\text { This is a discrete (DI) alarm. } \\
\text { Controller Set Point: } 40 \text { degrees Fahrenheit } \\
\text { Controller Set Point Basis: See instrument TIC- } \\
\text { AY101k102-1. }\end{array}$ \\
\hline
\end{tabular}

